\title{
KONTRIBUSI SAREKAT ISLAM DALAM MEMBENTUK MASYARAKAT MADANI MELALUI PENDIDIKAN
}

\author{
Mansur \\ Guru Besar Sekolab Tinggi Agama Islam Negeri (STAIN) Salatiga \\ Mansur_ismailnaimab@yaboo.com.
}

\begin{abstract}
This research will examined the purpose and principles of the Sarekat Islam education and the education of Sarekat Islam (SI) empowering communitie. This research is the field research with qualitative data. Method of collecting the data through observation, documentation, interviews, and libraries research. The data analysis will in the form of reflective thinking, deduction and induction. The findings of this study shows of education embodies a true muslim and a nationalis. Educational principles of instilling a sense of nationality, democracy, courage, a simple life, uphold degrees, selfreliance, and the integration of science of religion. finally the SI has been contributing about education system which was later used in the regulation of the education system in Indonesia.
\end{abstract}

Key words: Islamic Education, Sarekat Islam, Community Empowerment

\begin{abstract}
Abstrak
Penelitian ini akan mengkaji tentang tujuan dan prinsippendidikan SI dan bagaimana pendidikan SI dalam memberdayakan masyarakat Penelitian ini merupakan penelitian lapangan (field research) dengan data kualitatif. Metode pengumpulan data melalui observasi, dokumentasi, wawancara, dan studi kepustakaan. Dalam analisis data interpretasinya menerapkan prinsip deduksi dan induksi. Temuan penelitian ini: Pertama, tujuan pendidikan SI mewujudkan muslim sejati sekaligus berjiwa nasionalis. Prinsip pendidikannya menanamkan rasa kebangsaan, demokrasi, keberanian, budi pekerti utama, bidup sederhana, menjunjung tinggi derajat, pencerdasan akal, kemandirian, dan integrasi ilmu umum dengan ilmu agama. Kedua, SI telab memberikan kontribusi tentang sistem pendidikan yang kemudian digunakan dalam regulasi sistem pendidikan di Indonesia.
\end{abstract}

Kata kunci: Pendidikan Islam, Sarekat Islam, Pemberdayaan Masyarakat 


\section{Pendahuluan}

Sejarah telah mencatat dengan jelas bagaimana perlakuan yang sangat tidak proporsional dilakukan oleh pemerintah kolonial terhadap rakyat Indonesia. Maka muncullah beberapa gerakan organisasi untuk menegakkan hak-hak rakyat dan menolak penolakan diskriminatif, di antaranya adalah Sarekat Islam (SI). S I adalah organisasi kemasyarakatan sebagai kelanjutan dari Sarekat Dagang Islam (SDI) yang didirikan tanggal 16 Oktober 1905 oleh H. Samanhudi dan diteruskan oleh HOS Tjokroaminoto ' Kumpulan Ketetapan-ketetapan Majlis Tabkim/Konggres Nasional ke-36, Jakarta, 1996: 6 dan Anggaran Dasar SI bab I Pasal I). Oleh karena itu setiap tahun SI selalu memperingati hari kelahirannya pada tanggal 16 Oktober tersebut. HOS Tjokroaminoto sebagai salah satu tokoh pendiri SI dan dia juga termasuk pahlawan nasional dalam memperjuangkan kemerdekaan bangsa Indonesia (Taufik Rachman, 1997: 20).

Pendidikan SI merupakan upaya counter attack kepada pihak Belanda yang berusaha menganaktirikan kaum inlander dalam bidang pendidikan pada khususnya dan persamaan hidup pada umumnya (MA. Gani, 1984: 129). Sebab pada saat itu orang Indonesia tidak diakui sebagai bangsa, tetapi hanya dipandang sebagai bumi putera (penduduk asli) saja dan diperlakukan sebagai penduduk kelas rendah atau kelompok tiga. Terdapat tiga kelompok sosial saat itu yakni: (1) orang Belanda; (2) orang asing termasuk Cina; (3) orang Indonesia yang termasuk kelompok rendahan (Takashi Shiraishi, 1997: 39).

Pendidikan yang diterapkan oleh Belanda tidak menguntungkan rakyat Indonesia karena pada dasarnya bertujuan untuk menjadikan warga negara yang mengabdi kepada kepentingan kolonial. Usaha pendidikannya juga dilakukan oleh misi zending, maka ada kecenderungan ke arah penetrasi agama sebagai salah satu langkah untuk memperkuat penjajah Belanda, sehingga dari maksud yang terselubung dari pendidikan kolonial itu telah menimbulkan rasa tidak senang pihak bangsa Indonesia Nugroho Notosusanto, 1986: 42). Berdasarkan latar belakang tersebut maka penelitian Ini Berjudul Kontribusi Sarekat Islam (SI) di Surakarta, 
Yogyakarta dan Banjarnegara dalam Membentuk Masyarakat Madani Melalui Pendidikan. Berpijak dari latar belakang di atas maka permasalaan penelitian ini dapat dirumuskan sebagai berikut:1) apa tujuan dan prinsip pendidikan SI ?; 2) bagaimana pendidikan SI dalam memberdayakan masyarakat?

\section{Pendidikan Islam}

Pendidikan adalah proses bimbingan atau pertolongan yang sengaja atau sadar diberikan oleh orang dewasa (pendidik) terhadap perkembangan jasmani dan rohani anak yang belum dewasa (anak didik) untuk membentuk kedewasaan (kepribadiannya). Pendidikan merupakan pemberdayaan manusia dalam menjalani kehidupan dan sekaligus untuk memperbaiki masa depan. Pendidikan merupakan suatu upaya mewariskan nilai yang akan menjadi penolong dan penuntun dalam menjalani kehidupan, sekaligus untuk memperbaiki nasib dan peradaban umat manusia (Mansur, 2004: 1). Tanpa pendidikan manusia sekarang tidak akan berbeda dengan manusia masa lampau, bahkan akan lebih rendah atau jelek kualitasnya (Mansur, 2004: 8). Masyarakat madani dapat diwujudkan antara lain dengan melalui peningkatan pendidikan umatnya. Hal ini berlaku juga bagi bangsa Indonesia yang mayoritas penduduknya beragama Islam (Azwar Anas, 1993: Xiii). Oleh karena itu menurut John Dewey pendidikan diartikan sebagai social continuity of life. Ada juga yang mengartikan bahwa pendidikan adalah it more narrowly as transmission from some person to others of the skills, the arts and the sciences (Kingsley Price, 1965: 4). Maka dengan melalui pendidikan Islam manusia akan mampu mengembangkan dirinya dan meningkatkan potensinya untuk memperbaiki kehidupan di masa depannya. Oleh karena itu institusi pendidikan Islam peran sertanya untuk perbaikan aspek kehidupan sangat penting dan dibutuhkan oleh masyarakat pada umumnya. Lembaga pendidikan Islam dituntut perannya untuk peduli dalam rangka memperbaiki kehidupan masyarakat.

Jadi yang dimaksud dengan pendidikan Islam di sini adalah segala usaha atau bimbingan untuk mengembangkan jasmani rohani (fitrah manusia dan sumber daya insani) yang dilandasi oleh nilai-nilai Islam, yakni berdasarkan ajaran agama Islam 
menuju terbentuknya kepribadian utama menurut ukuran-ukuran Islam. Kepribadian utama ini disebut kepribadian muslim, yakni kepribadian yang memiliki nilai-nilai agama Islam, memilih, memutuskan, berbuat dan bertanggung jawab sesuai dengan nilainilai Islam.

\section{Pendidikan dalam Pandangan Sarekat Islam}

SI adalah organisasi modern pertama dan terbesar sepanjang sejarah pergerakan nasional Indonesia yang sebelumnya bernama SDI. Perubahan ini dilatarbelakangi adanya keinginan perkumpulan berperan ke arah kemajuan di segala bidang dan bukan hanya berdagang saja. SDI yang dipelopori oleh H Samanhudi akhirnya berubah menjadi SI yang memainkan peranan sangat urgen, yakni sebagai penggerak utama dalam bidang politik praktis maupun dalam bidang pemberdayaan rakyat (Rahman, 1997:20). Pada awal abad 20 terjadi perubahan dari gerakan yang bercirikan ratu adil menjadi pengembangan intelektual, yaitu pendidikan. Pendidikan merupakan kebutuhan manusia yang harus dipenuhi, bahkan manusia akan menjadi manusia karena pendidikan (F. Rosenthal, 1971: 17).

Dengan demikian pendidikan sangat menentukan keberhasilan seseorang dalam memimpin organisasi. Terbukti dalam perjalanan SI ketika masih di bawah H. Samanhudi yang hanya mengenyam pendidikan rendah, tidak mempunyai pendidikan yang cukup memadai bagi seorang pemimpin maka strategi perjuangannya belum begitu sempurna. Hal itu bisa dilihat dari berbagai kelemahan yang muncul antara lain: tidak adanya pembekalan pendidikan yang bisa menjadi alat perjuangan efektif, dan belum mampu mengakomodir jumlah massanya yang banyak, sehingga sering muncul tindakan-tindakan sepihak dari anggotanya yang justru bisa memojokkan posisi organisasi di mata pemerintah Belanda. Dapat dikatakan permasalahannya yakni krisis pemimpin kharismatik berpengetahuan.

Terdapat beberapa penelitian maupun tulisan terdahulu yang mengkaji mengenai Sarekat Islam. Di antaranya Timur Jaylani (1959), The Sarekat Islam Movement Its Contribution To 
Indonesian Nationalism. Dalam penelitian ini dikatakan bahwa SI merupakan organisasi pertama dan terbesar yang memberikan pengaruh kebangsaan di Indonesia. Selanjutnya Endang Umiyati (2006), Sarekat Islam Semarang Tabun 1913-1920, Universitas Negeri Semarang. Dalam penelitian ini dikatakan bahwa SI Semarang merupakan cabang SI di Surakarta yang berasaskan Islam dengan tujuan awal berdirinya dilatarbelakangi faktor ekonomi yaitu persaingan dengan pedagang Cina. Karena pengaruh paham sosialisme revolusioner, SI Semarang menjadi radikal.

Nasihin (2009), Antara Islam dan Sosialisme Partai Sarekat Islam Indonesia (PSII) 1924-1945, UGM. Penelitian ini mengatakan bahwa SI berasaskan Islam dan memperjuangkan keadilan masyarakat. Suwanto (2003), Sarekat Islam Komunisme: Analisis Pecahnya Sarekat Islam Menjadi Sarekat Islam Merah dan Sarekat Islam Putih, UGM. Dalam penelitian ini dikatakan bahwa SI mengalami konflik internal yang terbagi menjadi SI putih dan SI merah yang menjadi komunis. Mukhlis (1996), Sarekat Islam Semarang 1913-1923 di Persimpangan Jalan, UGM. Dalam penelitian ini dikatakan bahwa SI di Semarang merupakan cabang dari SI Surakarta, merupakan organisasi yang besar pengaruhnya dalam pemberdayaan masyarakat terutama buruh dan tani di Semarang. Soe Hok Gie (2000) Di Bawah Lentera Merah, Riwayat Sarekat Islam Semarang 1917-1920. Dikatakan bahwa SI termasuk organisasi besar yang mempunyai semangat kebangsaan kuat, dengan landasan agama Islam. Takashi Siraishi (1997) Zaman Bergerak: Radikalisme Rakyat di Jawa 1912-1926. Dikatakan bahwa semua anggota SI bersaudara, terlepas dari umur, pangkat dan status. Oleh karena itu hampir semua rakyat Indonesia menerima dan memasuki organisasi SI sehingga SI pada masa itu menjadi organisasi terbesar di Indonesia. Muyassarah (2004) Pemikiran Ekonomi HOS Tjokroaminoto (Sebuah Tinjauan Terbadap Sarekat Islam), UII. Dalam penelitian ini dikemukakan bahwa Pemikiran HOS Tjokrominoto sebagai penggerak organisasi SI untuk memajukan kemajuan dalam semua aspek kehidupan pada masa kolonial Belanda. Jadi pemikiran HOS Tjokroaminoto menjiwai terhadap pemikiran SI, sehingga berbicara mengenai HOS Tjokrominoto identik dengan SI, dapat diaplikasikan dalam kondisi sekarang. Tepatnya saat kondisi mengalami krisis 
ekonomi, dalam menumbuhkan ekonomi hendaknya dimulai dari bawah yaitu berbasis kerakyatan. Maksud kerakyatan untuk mewujudkan ekonomi yang tumbuh sehat dan berkualitas peduli pada usaha kecil menengah (UKM). Dengan UKM yang tumbuh pesat menandakan full employment bisa diwujudkan dengan berpegang teguh pada trilogi SI.

Siti Badriyah, IAIN Sunan Kalijaga, Pandangan HOS Tjokroaminoto tentang Sosialisme. Dalam penelitian ini dikatakan bahwa setiap perjuangan HOS Tjokroaminoto selalu berkaitan dengan SI. Berlaku sosial secara Islam yang disebut adil, yakni adil terhadap semua manusia dan selalu memperjuangkan rakyat kecil karena saat itu bangsa Indonesia masa yang melarat dan mengalami kehidupan yang serba buruk. Moh. Rosyid (2012) Jejak Kesinambungan Madrasah Diniyah Muawanatul Muslimin Sejak 1915 Hingga 2012 di Kudus: Studi Sejarah. Dalam penelitian tersebut dikatakan bahwa tahun 1915 telah ada keberanian suatu organisasi mendirikan madrasah di tengah kekuasaan Belanda yang berbendera Islam. Dalam penelitian tersebut belum disebutkan bahwa bendera Islam itu gagasan organisasi SI dan belum disebutkan lulusan dari Madrasah Muawanatul Muslimin Kenepan (M3K) Kudus. Mengomentari penelitian tersebut maka menurut saya bahwa bendera Islam yang dimaksud adalah SI yang dimotori oleh HOS Tjokroaminoto dan lulusan pertama kali di M3K tersebut adalah KH Arwani Amin. (Hal ini juga dikuatkan wawancara saya dengan KH. Mansur ketua Madrasah Muawanatul Muslimin Kenepan/M3K itu di Kudus). Dari beberapa penelitian dan tulisan di atas ternyata belum ada yang membahas atau meneliti SI yang ditinjau khusus dari pendidikannya dalam pemberdayaan masyarakat untuk membentuk .masyarakat madani.

\section{Metode Penelitian}

Jenis, desain dan lokasi penelitian

Penelitian ini merupakan penelitian lapangan (field research), dan penelitian ini bersifat kualitatif deskriptif, yaitu peneliti menjajaki, menguraikan, dan menerangkan pendidikan SI dalam membentuk masyarakat madani. Obyek penelitian difokuskan di tiga tempagt, 
yaitu Surakarta, yogyakarta dan banjarnegara. Peneliti mengambil Surakarta karena di kota ini SI pertama kali berdiri. Yogyakarta, karena satu-satunya propinsi di Indonesia yang mempunyai perguruan tinggi atau universitas milik SI. Adapun di Banjarnegara merupakan kota atau kabupaten yang terbanyak memiliki sekolah atau madrasah sebagai lembaga pendidikan milik SI.

\section{Teknik pengumpulan data dan metode}

Untuk memperoleh data, dipergunakan cara berikut ini: dokumen, observasi, wawancara dan penelusuran literatur kepustakaan. Untuk memahami gejala struktural dan kultural maka digunakan pendekatan sosio kultural. Studi kritis juga dilakukan untuk mengkritisi sejauhmana organisasi SI memberdayakan masyarakat melalui pendidikan, sementara organisasi tersebut juga bergelut dalam dunia politik. Melihat pada keterkaitannya dengan penafsiran bukti, maka mempunyai hubungan yang erat dengan metode deskriptif.

\section{Teknik analisis data}

Dalam penelitian ini digunakan pula metode analisis terhadap data-data yang telah terkumpul melalui dokumen, observasi, interview atau wawancara untuk memperoleh perspektif yang jelas. Selanjutnya agar interpretasinya tetap ilmiah, maka ditempuh cara berpikir reflektif, maksudnya mondar mandir antara deduksi dan induksi.

\section{Analisis}

\section{Trilogi Landasan Prinsip Gerakan SI}

Untuk memajukan pendidikannya maka SI mempunyai persyaratan atau modal saling kait mengkait dan tidak bisa dipisahkan satu dengan lainnya yang disebut "trilogi SI" (Hasil olahan wawancara peneliti dengan Bapak Ismail Jaelani selaku pengurus SI pusat di Yogyakarta) yakni:

1. Sebersih-bersih Tauhid

Dengan memakai landasan ini jelaslah bahwa perjuangan bukan karena interest pribadi (personal interest), bukan karena 
kepentingan kelompok (group interest), bukan pula karena kepentingan keluarga (family interest). Tetapi berjuang karena kepentingan negara, bangsa dan agama dan dalam rangka tujuan yang lebih jauh yakni berjuang karena Allah semata. Masalah hidup memang kompleks dan berliku-liku, kadang menggembirakan tapi kadang menusuk hati dan menekan perasaan. Namun demikian tidak boleh risau dan bersedih hati, harus selalu sadar bahwa semua perbuatan manusia tidak ada yang lepas dari kekuasaan Tuhan. Manusia bisa menipu orang lain dan membohongi masyarakat, tetapi tidak bisa menipu Tuhan dan dirinya sendiri. Oleh karena itu prinsip sebersih-bersih tauhid harus dimiliki kalau ingin mancapai hasil yang baik dan halal (Wawancara peneliti dengan pengurus SI Pusat di Yogyakarta). Sebersih-bersih tauhid merupakan landasan yang paling kokoh dalam menghadapi berbagai macam poblema kehidupan dan sebagai sebuah sinar cahaya yang terang benderang di tengahtengah suasana yang gelap. Hanya sebersih-bersih tauhid merupakan senjata ampuh untuk menjauhkan diri dari godaan setan.

\section{Setinggi-tinggi Ilmu Pengetahuan}

Menurut SI Allah tidak meyuruh umatNya hanya mengejar akherat semata dengan tidak memperhatikan kesejahteraan hidupnya di dunia ini, tetapi Allah menghendaki agar umatNya hidup bahagia dan sejahtera di muka bumi serta kehidupan bahagia, tenteram dan damai, sejahtera serta abadi dengan segala kenikmatan yang ada dalam surga (Wawancara dengan pengurus SI di Yogyakarta) Manusia dapat mengatur perkara-perkara ibadat untuk kepentingan akherat dan untuk kepentingan dunia atau mencapai dunia akherat kalau mempunyai kepandaian ilmu (wetenschaps). Islam menghendaki kemerdekaan pikiran (menuntut ilmu) dengan berdasar kepada kesungguhan iman kepada Allah. SI menegaskan, umat Islam di dunia dan khususnya di Indonesia masih banyak yang hidup dalam kemiskinan dan kemelaratan (verploreariseeren). Adapun faktor yang menyebabkan kemiskinan dan kemelaratan itu karena umat Islam belum banyak mempergunakan akal untuk memecahkan berbagai problema kehidupan dan kemusykilan yang terdapat 
di alam ini (MA Gani, 1984: 253). Jadi umumnya umat Islam baru sampai kepada suatu kebanggaan bahwa al-Qur'an sesuai dengan segala kehidupan yang serba modern dan sesuai dengan segala tempat dan waktu. Karena akal belum digunakan, ilmu pengetahuan belum dikembangkan, maka umat Islam selalu berada dalam posisi yang terpojok, miskin dan hina. Justru Allah menyuruh manusia belajar untuk membaca dan menulis agar dapat menggali rahasia-rahasia alam dengan menggunakan ilmu pengetahuan (Amelz, 1955: 45). Bahkan ayat pertama yang diturunkan Allah mengandung perintah agar manusia tahu membaca dan menulis sehingga terlepas dari kegelapan dan kebodohan yang ayat pertama itu mengandung intisari bahwa manusia janganlah membiarkan dirinya tenggelam dalam kegelapan dan kebodohan. Dengan membaca manusia, dapat memperoleh ilmu (MA Gani, 1984: 185).

Demikian juga untuk memecahkan segala sesuatu yang terkandung dalam alam semesta ini harus dengan ilmu. Untuk itu semua otak harus dipergunakan dan ilmu pengetahuan harus dicari, diolah kemudian diterapkan untuk kepentingan umat manusia. Seseorang yang beragama tanpa ilmu ibarat orang yang lumpuh, dan orang yang berilmu tanpa agama sama halnya ia seperti orang buta. Karena orang yang berilmu akan mendapatkan keutamaan dari Allah. Allah telah menciptakan segala sesuatu yang ada di langit, di bumi dan memerintahkan kepada umat manusia agar mempergunakan akal. Ilmu pengetahuan dapat digunakan untuk mengolah semua isi yang terkandung di dalamnya. Manusia harus berpikir, mengolah dan bekerja untuk mendapatkan hasil yang akan dimanfaatkan untuk kepentingan dan kesejahteraan manusia sendiri. Tetapi umat Islam sendiri yang langsung melibatkan dirinya dalam bidang ilmu pengetahuan jumlahnya sangat terbatas. Akibatnya kemampuan untuk menggali sumber-sumber alam juga sangat terbatas, dan karena itu umat Islam sendiri banyak berada dalam taraf kemiskinan. Perkembangan teknologi modern hanya mungkin dipahami kalau memiliki ilmu pengetahuan. Jelaslah bahwa agama pada hakekatnya bukan penyebab bagi kerobohan suatu negara dan kehancuran umat manusia, namun sebaliknya 
Islam merupakan faktor yang kuat untuk menuju kemajuan, dan yang menyebabkan timbulnya kemajuan ilmu. Maka agar umat Islam lepas dari kebodohan dan kegelapan, syarat utama adalah tuntutlah ilmu pengetahuan setinggi-tingginya sejauh batas-batas yang diperkenankan Allah, dan sejauh batas kemampuan otak manusia itu sendiri, yakni melalui pendidikan.

3. Sepandai-pandai Siyasah (Strategi)

Menurut SI, politik atau siyasah itu dapat dibedakan menjadi dua, yakni: Theoritische politiek, yakni sebagai ilmu pengetahuan (wetenschaps). Practische politiek, yakni sebagai kepandaian, keterampilan dan kecerdikan. (Wawancara dengan pengurus SI Pusat di Yogyakarta). Yang dimaksud istilah sepandai-pandai siyasah di sini selain ilmu pengetahuan tentang politik tetapi terutama dalam pelaksanaannya dititikberatkan kepada arti kedua yakni kepandaian, keterampilan dan kecerdasan. Karena dalam kehidupan bermasyarakat meliputi ketiga-tiganya sebagai kemampuan dan keahlian dalam menerapkan kebijaksanaan kehidupan bermasyarakat dan bernegara (MA Gani, 1984 :197). Sepandai-pandai siyasah tidak berdiri sendiri tetapi selalu berkesinambungan trilogi lainnya. Hal ini disebabkan pelaksanaan politik praktis tidak mungkin lepas dari sebersihbersih tauhid maupun setinggi-tinggi ilmu pengetahuan.

Kalau prinsip trilogi ini dilepaskan dalam politik praktis maka para praktisi lebih cenderung bergerak ke arah yang kotor. Sedangkan prinsip yang kotor itu sangat dicela oleh ajaran Islam, sebab dapat merusak dan melanggar sopan santun politik dan hak-hak asasi manusia yang dijunjung tinggi oleh agama Islam. Memang ketiga prinsip itu tidak dapat dipisah-pisahkan di mana menurut Ismail Jaelani seorang pengurus pusat SI dan satu-satunya dosen ke-SI-an di Universitas Cokroaminoto Yogyakarta (UCY) mengatakan bahwa trilogi tersebut pada waktu lahirnya SI, Islam masih berbaur dengan budaya sehingga Islam hanya sebagai azimat yang pada hakekatnya tidak sesuai dengan Islam. Seseorang hanya mengambil karomahnya saja (kekuatan batin yang dikejar), sehingga ilmu agamanya kurang kelihatan. Karena pada saat itu bangsa Indonesia terjajah sehing- 
ga rakyat menginginkan adanya kekuatan fisik. Maka dengan kondisi itulah SI berusaha agar rakyat bisa menjadi bertauhid semurni-murninya (Wawancara peneliti dengan dosen ke-SI-an di Universitas Cokroaminoto Yogyakarta / UCY).

\section{Tujuan Gerakan SI}

SI didirikan atas empat pokok pikiran yang menjadi tujuan gerakannya. Pertama, memperbaiki nasib rakyat dalam bidang sosial ekonomi. Kedua, mempersatukan pedagang batik agar dapat bersaing. Ketiga, hendak mempertinggi harkat dan martabat bangsa Indonesia yang pada saat itu sering disebut bumi putera. Keempat, memperkembangkan serta memajukan Islam melalui pendidikan (Wawancara dengan Bapak Ismail Jaelani pengurus SI di Yogyakarta). Tujuan pada saat permulaan bentuknya sangat sederhana, kemudian lebih dipertegas oleh SI dengan Akte Notaris 10 September 1912 Drs. Susanto Tirtoprojo SH. Di dalam Akte Notaris tersebut ditetapkan tujuan SI sebagai berikut: Pertama, memajukan perdagangan. Kedua, memberikan pertolongan kepada anggota-anggota yang mengalami kesukaran, jadi semacam koperasi bantu-membantu. Ketiga, memajukan kepentingan jasmani dan rohani dari penduduk asli. Bahwa tujuan tidak hanya terbatas kepada anggota saja, tetapi perkumpulan meluas kepada masyarakat yakni kepentingan penduduk asli. Keempat, memajukan kehidupan agama Islam (Susanto Tirtoprodjo, 1968: 24).

Jadi usahanya untuk memperbaiki dan mengembangkan ekonomi, sosial koperasi, pendidikan serta melaksanakan dakwah Islam tetap menjadi tujuannya yang utama (Amelz, 1955: 37-38). Jadi usaha tujuan pendidikan dapat dinyatakan dengan kalimat yang singkat yakni memajukan kepentingan jasmani dan rohani dari penduduk asli (MA Gani, 1984: 28) Pada saat lahirnya SI pendidikan rakyat sangat minim kalau ada yang menikmati pendidikan baik menengah maupun tingkat tinggi hanya terbatas pada golongan tertentu saja, yaitu golongan ningrat dan priyayi, bangsa Belanda sendiri dan orang-orang Timur Asing. Oleh karena itu SI mengharapkan penduduk asli dapat mencapai tujuan tersebut agar tidak hanya terbatas pada golongan tertentu. Dengan demikian tujuan SI sejak semula dapat disimpulkan dalam kalimat 
yang sederhana sebagai berikut: a).Melaksanakan dakwah Islam yang seluas-luasnya.b).Menghidupkan solidaritas sosial agar tali persaudaraan tumbuh atas dasar kasih sayang dan saling bantumembantu sama lainnya. c).Membangun kehidupan ekonomi rakyat agar terlepas dari kemiskinan dan perbudakan dan dalam bentuk apapun juga. d).Mengembangkan dan melaksanakan pendidikan untuk kecerdasan rakyat dari segenap lapisan. Dapat dikatakan bahwa tujuan SI adalah untuk mewujudkan suatu kehidupan manusia yang sempurna sebagai hamba Allah dengan berpedoman pada al-Qur'an dan Sunnah Rasul dalam kerangka pembangunan manusia Indonesia seutuhnya yang berdasarkan Pancasila.

\section{Kontribusi Pendidikan Sarekat Islam dalam Memberdayakan Masyarakat}

Pendidikan Sarekat Islam mempunyai arti penting sebagai pemberdayaan masyarakat Indonesia, membebaskan dan menyadarkan masyarakat (Hasil olahan wawancara peneliti dengan pengurus SI di Yogyakarta):

1. Pendidikan Sebagai Proses Pembebasan

Pendidikan SI sebagai paradigma pembebasan pada masa dahulu maupun masa sekarang untuk membebaskan dari kebodohan dan keterbelakangan. (Wawancara dengan pengurus SI di Yogyakarta). Oleh karena itu SI berusaha memberdayakan masyarakat dengan membebaskan bangsa Indonesia yakni melalui pendidikan. Pendidikan Islam bisa diformulasikan sebagai upaya pemanusiaan manusia dengan cara manusiawi untuk berkembang agar mempunyai nilai-nilai kemanusiaan yang tinggi. SI memandang bahwa dengan pendidikan Islam mampu memberdayakan masyarakat Indonesia bisa membebaskan dari kebodohan, keterbelakangan, dan penindasan.

Dengan pendidikan dapat mengentaskan manusia dari yang semula tidak berpengetahuan menjadi berpengetahuan, yang semula tidak kreatif kemudian ditumbuhkembangkan menjadi kreatif-produktif sehingga tahu akan hak-hak sebagai warga untuk sama-sama membebaskan dari penjajah (HOS Tjokroaminoto, 1955: 54). Dengan pendidikan mampu mengantarkan 
manusia dari yang semula pasif, statis, dan regresif menjadi aktif, dinamis, dan progresif menuju masyarakat madani di Indonesia. Dengan pendidikan dapat membawa manusia ke konteks yang lebih adil, baik dalam konteks belajar maupun sosial. Dalam konteks belajar, misalnya dari yang semula monoton, monolog dan otoriter menjadi variatif, dialogis, dan demokratis. Hal tersebut dapat memberikan kontribusi pada pembelajaran sekarang tidak hanya ceramah saja tetapi perlu variatif, dialogis serta kontekstual. Dengan demikian pendidikan sebagai praktek pembebasan dari penindasan, mengoptimalkan keadilan di dalam semua konteks kehidupan, tidak adanya diskriminasi. Dengan demikian melalui pendidikan pada zaman dahulu mampu memberdayakan masyarakat untuk membrontak penjajah demi membebaskan dari penindasan penjajah.

Dalam konteks sekarang ternyata pendidikan mampu memberdayakan masyarakat lebih mengetahui informasi dan membebaskan dari kebodohan dan keterbelakangan, serta kemiskinan. Sistem pendidikan SI mulai dari tingkat dasar sampai perguruan tinggi menggunakan nama pendidikan tingkat dasar (Lager Onderwijs), pendidikan menengah (Middelbaar Onderwijs), serta pendidikan tinggi (Hoger Onderwijs). Dalam sistem penggajian Sarekat Islam sangat memperhatikan jenjang pendidikan tersebut, sementara Belanda memperlakukan sama gaji tanpa mempertimbangkan jenjang pendidikannya. Dalam kondisi masyarakat madani di Indonesia sekarang ini ternyata sistem penggajian pegawai negeri sipil digaji sesuai dengan taraf pendidikannya. Lulusan pendidikan tingkat dasar jika diangkat jadi pegawai negeri sipil mendapat golongan satu, lulusan pendidikan menengah menjadi golongan dua serta lulusan pendidikan tinggi menjadi golongan tiga, dengan gaji yang berbeda antara golongan satu, dua dan tiga. Maka semakin pendidikannya tinggi golongan kepegawaiannya semakin tinggi otomatis akan mendapat gaji yang lebih tinggi sehingga akan memberdayakan masyarakat untuk bebas dari kemiskinan sehingga mampu mewujudkan masyarakat madani yang diidamidamkan. 
2. Pendidikan Sebagai Proses Penyadaran

Pendidikan SI juga menyadarkan rakyat yang belum mampu menggunakan akal sebaik-baiknya. Oleh karena itu SI dalam mewujudkan masyarakat madani di Indonesia dengan mendidik masyarakat atau rakyat di dalam berpikir untuk menggunakan kekuatan akal yang dimiliki oleh manusia agar dimanfaatkan untuk kesejahteraan baik di dunia maupun di akhirat (Wawancara dengan Bapak Joko pengurus lembaga pendidikan Cokroaminoto di bawah naungan SI di Surakarta). Dengan demikian SI pada zaman dahulu juga memberdayakan pemerintahan desa dengan mengadakan perbaikan dengan meningkatkan pendidikan mereka terutama untuk dapat diangkat menjadi kepala desa minimal harus lulus sekolah bumi putera kelas dua. Sesudah tahun 1907 terdapat tiga tipe pendidikan rendah untuk golongan rakyat Indonesia yakni: Sekolah kelas satu, lamanya tujuh tahun. Tingkatan sekolah ini sejak tahun 1912 sama dengan tingkatan sekolah dasar Eropa.

Sesudah reorganisasi tahun 1914 tipe sekolah ini disebut Hollands Inlandie School (HIS). Sekolah kelas dua, lamanya tiga tahun. Program pelajarannya yakni membaca dan menulis dalam bahasa daerah, berhitung dan fakultatif beberapa mata pelajaran yang diajarkan di sekolah kelas satu. Sekolah desa, merupakan sekolah paling sederhana. Program pelajarannya tidak lebih banyak dari pemberantasan buta huruf (APE. Korver, 1985: 102). Kepala desa harus tunduk kepada Dewan Desa yang anggotanya terdiri dari wakil-wakil penduduk desa. Kontribusi SI terhadap pemerintahan desa maka sekarang terbentuklah semisal Lembaga Musyawarah Desa (LMD) di seluruh Indonesia dan menurut SI bahwa Dewan Desa itu perannya lebih besar artinya daripada Dewan Rakyat (Volksraad). Jelas sekali penekanan konsep yang ingin dikehendaki SI dalam metode pendidikannya yaitu konsep penyadaran kepada rakyat. Hal yang menonjol bahwa pendidikan sebagai proses penyadaran yakni menumbuhkan kesadaran eksistensial potensial manusia yang pada gilirannya dapat menumbuhkan kemampuan kritis, aktif, berintegrasi dengan dunia, mendinamisir, menguasai dan memberikan arti temporal terhadap ruang geografis dan menjaga kebudayaan sendiri. 
Maka prinsip penyadaran (konsientisasi) dalam pendidikan memiliki pengertian usaha penyadaran manusia dari eksistensi potensialnya yang kodrati dan pasif untuk dikembangkan menjadi potensi yang aktif agar dapat merekayasa kehidupan dan lingkungannya sesuai dengan kemampuannya. Hal ini adanya kemiripan dalam pandangan filsafat pendidikan progressivisme mengenai siapa peserta didik itu. Peserta didik mempunyai potensi akan kemampuan intelegensi yang digunakan untuk memecahkan problema kehidupan -menurut filsafat pendidikan progressivismependidikan berfungsi sebagai penyempurna intelegensi. Juga tercermin adanya kemiripan dengan pandangan empirisme John Lock, mengenai pandangan arti pentingnya pengalaman bagi manusia, dalam hal ini sebagai peserta didik. Sebuah konsep pendidikan yang realistis dari kondisi sosio kultural masyarakat yang terbelenggu oleh sistem kolonial dan tradisi kebangsawanan yang feodalistik, SI mampu memberikan alternatif bagi gerakan kerakyatan dengan pendidikan yang bertumpu pada asas-asas penyadaran akan persamaan hak, rasa kemanusiaan dan kemerdekaan yang dilandasi oleh ideologi keislaman sebagai satu-satunya ideologi pembebasan. Karena memang segala aspek kehidupan manusia itu telah tercakup oleh kesempurnaan dan kesucian sumber Islam (Keputusan dan Ketetapan Majlis Tahkim/Konggres Nasional ke36 tentang Program Kerja SI 1996-2001: 219). Oleh karena itu SI berusaha meningkatkan derajat rakyat Indonesia dengan jalan memajukan pendidikan mereka.

Dalam sistem pendidikan, SI mewajibkan rakyat untuk sadar berpendidikan sampai umur 15 tahun, hal ini memberikan kontribusi pada pendidikan di Indonesia sekarang ini bahwa anak didik itu wajib menyelesaikan pendidikan dasar sampai SMP yang mana jika dilihat dari segi umur usia lulusan SMP itu sekitar 15 tahun. Dalam sistem pendidikan, menurut SI murid setelah menyelesaikan jenjang pendidikan tinggi (Hoger Onderwijs), mereka diakui kecakapannya baik dalam ilmu-ilmu agama ataupun ilmu-ilmu keduniaan, sehingga murid akan diberi gelar guru jika telah menyelesaikan pada jenjang pendidikan tinggi. (Wawancara dengan pengurus SI di Yogyakarta). Hal ini memberikan kontribusi pada sistem pendidikan nasional di Indonesia yakni untuk diangkat dan diakui sebagai guru profesional 
minimal harus berpendidikan sarjana atau pendidikan tinggi. Dengan adanya pendidikan termasuk pendidikan yang dikelola oleh SI sekarang ini mempunyai nama pendidikan Cokroaminoto yang tersebar di seluruh pelosok tanah air Indonesia dari tingkat dasar $\mathrm{SD} / \mathrm{MI}$ sampai perguruan tinggi/universitas Cokroaminoto, mampu menyadarkan bangsa Indonesia terhadap jati dirinya sehingga mampu membangkitkan masyarakat Indonesia untuk lebih maju dan berkualitas menuju masyarakat madani (Wawancara dengan pengurus pendidikan Cokroaminoto di Banjarnegara). Dalam SI juga diberikan pendidikan tentang kepanduan atau kepramukaan untuk melatih kedisiplinan dan kepemimpinan. Dari sekolah SI memunculkan nama yang harum yakni Sunarto yang pernah menjabat sebagai ketua Pandu atau Pramuka tingkat Jawa Tengah dan sekaligus sebagai perintis kemerdekaan (Wawancara dengan pengurus pendidikan Cokroaminoto di Solo).

\section{Dasar dan Tujuan Pendidikan SI}

SI mengambil dasar dalam pelaksanaan pendidikan dari alQur'an dan al-Hadis yakni menuntut ilmu adalah wajib bagi orang Islam laki-laki dan perempuan (Hal ini dikuatkan hasil wawancara peneliti dengan pengurus SI di Surakarta). Tujuan pendidikan bagi SI untuk menjadikan atau membentuk anak didik agar menjadi muslim yang sejati dan sekaligus menjadi seorang nasionalis yang berjiwa besar dan penuh kepercayaan pada dirinya sendiri, pada masa dahulu maupun sampai sekarang (Wawancara peneliti dengan pengurus SI di Yogyakarta). Dengan demikian pendidikan bertujuan menjadikan muslim sejati dan sekaligus nasionalis, mempunyai keseimbangan ilmu modern (duniawi) dengan ilmu agama. Oleh karena itu di samping mempunyai otak cerdas juga mempunyai budi pekerti utama, hidup sederhana, punya keberanian dan kemandirian, serta mempunyai rasa cinta tanah air.

\section{Prinsip Pendidikan SI}

Untuk mencapai tujuan pendidikan, SI mempunyai prinsipprinsip pokok yang perlu diperhatikan dalam pelaksanaan pendidikan (Wawancara dengan Bapak Ismail Jaelani pengurus SI di Yogyakarta): 
1. Pendidikan dan pengajaran di sekolah haruslah pengajaran yang di dalamnya mengandung isi dan arah pendidikan yang mendukung tercapainya anak didik sebagai muslim sejati dan nasionalis yang berjiwa besar dan penuh percaya diri.

2. Pelaksanaan pendidikan haruslah ditanam cita-cita demokrasi sebagai benih perjuangan dalam usaha mengangkat derajat dan martabat bangsa.

3. Pendidikan menanamkan prinsip-prinsip keberanian yang bersifat luhur, hati yang ikhlas, kesetiaan dan kecintaaan kepada yang benar secara konsekuen.

4. Pendidikan menanamkan budi pekerti yang halus dan tingkah laku penuh sopan santun dan peradaban yang tinggi.

5. Pendidikan menanamkan prinsip hidup sederhana, sikap saleh dalam kehidupan beragama bermasyarakat dan bernegara.

6. Pendidikan menanamkan prinsip menjunjung tinggi dan menghargai derajat serta martabat bangsa sendiri.

7. Pendidikan erat hubungannya dengan rasa nasionalisme tidak boleh menyebabkan anak terpisah dari adat istiadat dan kehidupan bahagia dalam rumah tangga.

8. Pendidikan selain mampu memperkuat rasa kebangsaan, juga mampu meningkatkan kecerdasan bangsa dan memupuk sikap watak yang bertanggung jawab.

9. Pengaruh negatif yang datangnya dari luar ataupun dari masyarakat sendiri harus dicegah sehingga anak sungguh-sungguh mendapat pendidikan dan pengajaran yang memungkinkan mereka tetap menjadi muslim sejati.

10.Pendidikan dan pengajaran menurut SI, bahwa ilmu pengetahuan di dunia dan ilmu pengetahuan agama Islam tidak boleh dipisahpisahkan.

11.Pendidikan sebagai pencerdasan akal dan membentuk sifat kemandirian. Dengan kata lain dunia dan akherat berjalan paralel, integrasi dan seimbang.

Banyak sekolah atau lembaga pendidikan Islam Cokroaminoto di bawah naungan organisasi SI yang terbanyak se wilayah Jawa Tengah yakni di kabupaten Banjarnegara: TK ada 3, RA ada 75, 
SD ada 1, MI ada 55, SMP ada 5, MTs ada 6, SMA ada 1, MA ada 3, dan SMK ada 3 buah (Data Yayasan Pendidikan Cokroaminto SI Banjarnegara). Lembaga pendidikan Islam Cokroaminoto di bawah naungan organisasi SI di Solo tempat lahirnya SI: 3 buah TK, 2 SD, 2 SMEA, 1 SMU dan 1 STM. Universitas yang dimiliki oleh SI antara lain Universitas Cokroaminoto Yogyakarta, pada awalnya dahulu universitas tersebut terletak di Solo juga, namun karena banjir maka dipindah ke Yogyakarta, sedangkan di Solo muncullah Universitas Sebelas Maret/UNS. Jadi SI memberikan kontribusi berdirinya universitas tersebut (Hasil wawancara dengan pengurus SI dan pendidikan Cokroaminoto di Solo). Jadi lembaga pendidikan SI di Yogyakarta terdapat Universitas Cokroaminoto Yogyakarta.

Secara singkat jumlah lembaga pendidikan Sarekat Islam dapat dilihat dalam tabel berikut ini:

Tabel 1

Jumlah Sekolah/Madrasah SI di Surakarta

\begin{tabular}{clc}
\hline No. & Sekolah/Madrasah & Jumlah \\
\hline 1 & TK/RA & 3 \\
2 & SD/MI & 2 \\
3 & SMP/MTs & 2 \\
4 & SMU/MA & 1 \\
5 & SMK & 3 \\
\hline
\end{tabular}

Sumber: hasil wawancara

Tabel 2

Jumlah Sekolah/Madrasah SI di Banjarnagara

\begin{tabular}{clc}
\hline No. & Sekolah/Madrasah & Jumlah \\
\hline 1 & TK/RA & 78 \\
2 & SD/MI & 56 \\
3 & SMP/MTs & 11 \\
4 & SMU/MA & 4 \\
5 & SMK & 3 \\
\hline
\end{tabular}

Sumber: hasil wawancara 
Banyak output yang dihasilkan dari pendidikan SI yang berperan sebagai tokoh agama, bangsa dan negara sehingga mampu mewujudkan masyarakat madani di Indonesia. Antara lain Sunarto yang pernah menjadi ketua Pandu atau Pramuka Jawa Tengah, dari seorang nasionalis muncullah Soekarno sebagai bapak negara yang telah menjadi presiden pertama RI mendapat pendidikan SI sekaligus sebagai anak menantu dari HOS. Tjokroaminoto pemimpin SI. Beberapa anggota BPUPKI, PPKI, perumus UUD 1945 juga banyak dari kader SI. Dari ulama dan tokoh Nahdlatul Ulama yang banyak mendapat pendidikan SI dan sebagai lulusan pertama Madrasah Muawanatul Muslimin Kenepan (M3K) yang didirikan SI tahun 1915 yakni KH. Arwani Amin sebagai ulama besar kharismatik di Kudus keturunan Diponegoro yang mewariskan pesantren Arwaniyah Kudus, dan perintis Tashwiquththullab Salafiyah (TBS) merupakan lembaga pendidikan Islam yang maju dan eksis sampai sekarang (Wawancara dengan KH.Mansur selaku ketua M3K di Kudus). Dari tokoh Muhammadiyah KH. Ahmad Dahlan juga banyak mendapat pendidikan SI bahkan pernah menjadi penasehat SI (Takashi Shiraishi, 1997: 99). Jadi jika dilihat dari sejarah, NU dan Muhammadiyah banyak diwarnai SI, tokoh kedua organisasi tersebut sebagai orbitan pendidikan SI. Oleh karena itu ibarat dalam keluarga, SI menjadi orang tuanya sedangkan organisasi yang lain termasuk NU dan Muhammadiyah sebagai anak kandungnya (Mansur, 2004: vi). Suparman yang pernah menjabat sebagai wakil Mahkamah Agung RI juga banyak berkecimpung dan mendapatkan pendidikan Cokroaminoto di bawah naungan SI. Dapat dikatakan bahwa SI mampu memberikan warna terhadap sistem pendidikan nasional dan menelurkan orang-orang pilihan sebagai pemimpin agama, masyarakat, bangsa dan negara.

\section{Kesimpulan}

Sarekat Islam (SI) sebagai kelanjutan dari Sarekat Dagang Islam (SDI) tergolong sebagai salah satu organisasi perjuangan yang memegang peranan penting dalam memberdayakan masyarakat yakni dengan meningkatkan kesadaran rakyat serta dalam mewujudkan kemerdekaan Indonesia. Azaz SI yakni azaz 
agama Islam, kerakyatan, sosial ekonomi dan Pancasila. Trilogi SI yakni sebersih-bersih tauhid, setinggi-tinggi ilmu pengetahuan dan sepandai-pandai siyasah. Adapun tujuan SI didirikan, ada empat pokok pikiran yang menjadi tujuan perjuangannya, yakni: memperbaiki nasib rakyat dalam bidang sosial ekonomi, mempersatukan pedagang batik, hendak mempertinggi harkat dan martabat bangsa Indonesia asli yang pada saat itu sering disebut bumi putera, memperkembangkan serta memajukan melalui pendidikan.

Tujuan pendidikan SI yakni mewujudkan masyarakat Indonesia menjadi muslim sejati sekaligus berjiwa nasionalis dan berjiwa besar serta percaya diri. Adapun prinsip pendidikan SI yakni pendidikan haruslah menanamkan sifat nasionalis, demokrasi, keberanian, budi pekerti utama, hidup sederhana, menjunjung tinggi derajat bangsa sendiri, tidak terpisah dengan adat, pencerdasan akal, menanamkan rasa kebangsaan, sifat kemandirian, mencegah pengaruh negatif, dan tidak ada pemisahan antara ilmu umum atau ilmu dunia dengan ilmu agama Islam atau adanya integrasi antara keduanya.

Pendidikan SI sejak dahulu sampai sekarang yang terdiri mulai TK, SD/MI, SMP/MTs, SMA/MA dan Universitas yang bernama Cokroaminoto ikut serta dalam memberdayakan masyarakat, yakni menyadarkan masyarakat melalui pendidikan. S I telah memberdayakan masyarakat Indonesia, yakni menyadarkan lapisan luas masyarakat Indonesia dari keterbelakangannya. SI pulalah merupakan gerakan emansipasi di Indonesia pertama yang merekrut anggotanya dari seluruh Indonesia sebagai tahap penting kontribusinya dalam penyatuan bangsa Indonesia untuk bebas dari penjajah Belanda.

Banyak output yang dihasilkan dari pendidikan SI yang berperan sebagai tokoh agama, bangsa dan negara sehingga mampu mewujudkan masyarakat madani di Indonesia. Antara lain Sunarto yang pernah menjadi ketua Pandu atau Pramuka Jawa Tengah, Soekarno sebagai presiden pertama RI, KH. Arwani Amin tokoh NU dan ulama besar kharismatik, KH. Ahmad Dahlan tokoh Muhammadiyah. SI juga memberikan kontribusi terhadap sistem pendidikan 
nasional di Indonesia bahwa jenjang pendidikan itu mulai dasar, menengah, dan tinggi. Wajib belajar sampai SMP juga secara tidak langsung merupakan kontribusi SI yang mewajibkan masyarakat Indonesia wajib belajar sampai usia 15 tahun, berarti setaraf dengan usia SMP. Dalam sistem penggajian pegawai negeri juga merupakan kontribusi SI yang mana SI memberikan gaji sesuai dengan lulusan tingkat pendidikannya, pada waktu itu Belanda memberikan gaji yang sama tidak melihat jenjang pendidikannya. Untuk menjadi guru menurut SI juga harus lulusan pendidikan tinggi, maka hal itu memberikan kontribusi terhadap regulasi sistem pendidikan nasional di Indonesia sekarang, yakni guru profesional haruslah minimal lulusan sarjana.

\section{Daftar Pustaka}

Amelz, HOS Tjokroaminoto.1955. Hidup dan Perjuangannya. Jakarta: DPPSI.

Anas, Azwar Anas. 1993. Yogyakarta: Tiara Wacana Price, Kingsley. USA: Allyn and Bacon

Barnadib, Imam. 1987. Pendidikan Perbandingan-Buku Satu Dasar-dasar. Yogyakarta: Andi Offset.

Diana, Abdullah," Mengenang Jasa KH.M. Arwani Amin, dalam majalah" Ath-Thullab" No 1 tahun 1995

Gani, MA. 1984. Cita Dasar dan Pola Perjuangan Sarekat Islam, Jakarta: Bulan Bintang.

Het Indische Volk Organ ISDP. tanggal 20 Desember 1934 No. 16

Jaya, Tamar. dalam majalah Ilmu Politik Islam (Assiyasah. No. 5. Tahun 1974. Solo

Kasiati, Sarekat Islam yang Saya Kenal. Yogyakarta: UCY.

Keputusan-keputusan Majlis Tabkim/Konggres Nasional ke-36 tabun 1996. Jakarta. DPP SI.

Korver. APE. 1985. Sarekat Islam Gerakan Ratu Adil. Jakarta: Grafiti Pers.

Kuntowijoyo. 1994. Dinamika Sejarah Umat Islam Indonesia, Yogyakarta: Shalahudin Press dan Pustaka Pelajar.

Mansur. 2004. Sejarah Sarekat Islam dan Pendidikan Bangsa, Yogyakarta: Pustaka Pelajar. 
2004. Peradaban Islam dalam Lintasan Sejarah: Yogyakarta. Global Pustaka Utama.

.001. Diskursus Pendidikan Islam, Yogyakarta: Global Pustaka Utam

. 2006. Rekonstruksi Sejarab Pendidikan Islam di Indonesia. Jakarta: Dirjen Binbaga Depag RI.

Muhadjir. Noeng. 1998. Metodologi Penelitian Kebijakan. Yogyakarta: Rake Sarasin.

Noer, Deliar. 1994. Gerakan Modern Islam di Indonesia: 1900-1942. Jakarta: LP3ES.

Notosusanto, Nugroho. 1986. Sejarah Nasional Indonesia. Jakarta: Balai Pustaka.

Politieke Tribune, tanggal 22 Desember 1934 No. 5

Rachman, Taufik, "SI dalam Tragedi Politik Indonesia", dalam majalah Serikat, edisi perdana tahun VII/1997

Rosenthal, F. 1971. Four Essays on Art and Literature in Islam. Leiden: Ej. Brill.

Shiraishi, Takashi. 1997. Zaman Bergerak: Radikalisme Rakyat di Jawa 1912-1926, terj. Hilmar Farid. Jakarta: Grafiti Pers.

Tirtoprodjo, Susanto. 1968. Sejarah Pergerakan Nasional Indonesia. Jakarta: PT. Pembangunan

Tjokroaminoto, HOS. 1900. Islam dan Sosialisme. Jakarta: LPPSRI

------, Reglemet Umum Bagi Umat Islam. Jakarta: DPPSI

------ 1933. Cultur dan Adat Islam, Tanda-tanda Hidupnya Umat dan Perikatan (Gemeente) Islam, Jakarta

Yunus, Mahmud Yunus. 1979. Sejarah Pendidikan Islam. Jakarta: Hidakarya Agung.

------. 1995. Sejarah Pendidikan Islam di Indonesia, Jakarta: Mutiara Sumber Wijaya 